Tatiana V. Chernenkova ${ }^{1 *}$, Ivan P. Kotlov ${ }^{2}$, Nadezhda G. Belyaeva ${ }^{1}$, Olga V. Morozova', Elena G. Suslova ${ }^{3}$, Michail Yu. Puzachenko', Alexander N. Krenke ${ }^{1}$

${ }^{1}$ Institute of Geography, Russian Academy of Sciences, Staromonetniy pereulok 29, Moscow, 119017, Russia

${ }^{2}$ Severtsov institute of ecology and evolution, Russian Academy of Sciences, Leninsky ave. 33, Moscow, 119071, Russia

${ }^{3}$ M.V. Lomonosov Moscow State University, Leninskie Gory, Moscow, 119991, Russia

*Corresponding author: chernenkova50@mail.ru

\title{
SUSTAINABLE FOREST MANAGEMENT TOOLS FOR THE MOSCOW REGION
}

\begin{abstract}
The paper presents an inventory of current forest formations and a map of forest vegetation in the Moscow region. To assess current forest formations, an approach integrating both ground- and remote sensing data was applied. The transformation of forests in the Moscow region was evaluated by the criteria of changing the quality, quantity and spatial configuration of forests, in accordance with the model SLOSS (Single Large or Several Small). The conceptual model "Pressure-State-Response" (hereinafter PRS) was used to develop appropriate tools for sustainable environmental management in the region. The use of this model made it possible not only to assess the state of forests but also to determine the main impacts affecting them, as well as the effectiveness of measures aimed at optimizing environmental management regimes in order to maintain forest biodiversity. Complex assessment of sets of indicators for each group of PRS criteria is performed for the integrated multicriteria assessment of sustainable forest management within the boundaries of urban districts. The average normalized score was calculated for each group of criteria. Correlation between the scores of the groups of criteria evaluated and classification of administrative units according to the ratio of groups of the K-means method criteria performed. As a result of componentby-component evaluation, the values of indicators are presented in form of tables and map charts. Benchmarking of Specially Protected Natural Area (SPNA) system and reforestation activities is performed regarding to the forest biodiversity conservation in the urban districts. It is shown that single integrated assessment of the ecological value of the territory (the "State" criterion), an integrated assessment of impact factors (the "Load") and appropriate actions to maintain forest biodiversity (the "Response" criterion) can be considered as an expression of generalized information directly used in decision-making and assessment of current trends for a particular region.
\end{abstract}

KEY WORDS: Moscow region, forest biodiversity, sustainable management, anthropogenic impact, specially protected natural areas, reforestation

CITATION: Tatiana V. Chernenkova, Ivan P. Kotlov, Nadezhda G. Belyaev, Olga V. Morozova, Elena G. Suslova, Michail Yu. Puzachenko, Alexander N. Krenke (2019) Sustainable Forest Management Tools For The Moscow Region. Geography, Environment, Sustainability, Vol.12, No 4, p. 35-56

DOI-10.24057/2071-9388-2019-57 


\section{INTRODUCTION}

The problem of a sustainable combination of anthropogenic activities with the environment for the Moscow region is extremely urgent. Sustainable forest management means the management of forests in such a way as to ensure their biological diversity, productivity, renewal, viability, as well as environmental, economic and social functions (Ministerial conference 1993). The proximity to large urban clusters inevitably leads to a change in the natural properties of forests, while their importance for the city is extremely high. In general, the transformation of forests in conditions of long-term economic impact in accordance with the SLOSS model (Single Large or Several Small) occurs in different directions (Diamond 1975; Ovaskainen 2002; Ovaskainen 2012) (Fig 1).

Forest ecosystems of the Moscow region have been affected by deep anthropogenic transformations since the $16^{\text {th }}$ century, and the decline in the quality of forest cover in the region occurred in all directions with different intensity for different periods of its history. Zonal broad-leaved and coniferous forests have been replaced by secondary mostly small-leaved forests, thus there has occurred a change in biodiversity and a decrease in the resistance of ecosystems to external damaging factors. Recently, the region has been characterized by massive outbreaks of bark beetle in spruce plantations, intensive urban development, cottage construction, and recreation. As a result, active economy, including widespread forest plantation practice, has significantly changed the ecological and coenotic range 1 of zonal ${ }^{2}$ coniferous and broad-leaved forest communities. Today's forests in the Moscow region are distinguished by a number of features: a significant recreational pressure due to the high population density; limited purpose use of forests (in accordance with the Forest Code of the Russian Federation forests belong to the protection group); poor sanitary condition and unstable ecological situation caused by a lack of regulatory sanitary measures.

The wide experience in studying of typological diversity of forest communities and their dynamics is saved up for the forests

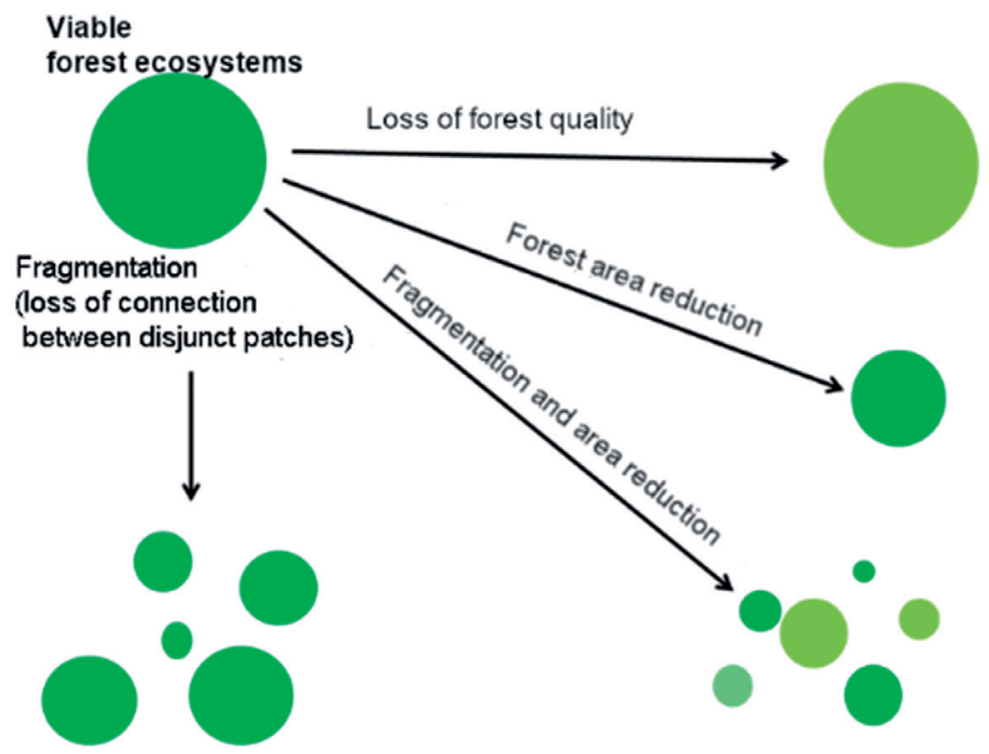

Fig. 1.Trends of forest changes at the regional level (Ovaskainen 2002; Ovaskainen 2012 as modified) 
of the Moscow region (Konovalov 1929; Byazrov et al. 1971; Kurnaev 1968; Forests 1982; Forests 1987; Forests 1985; Dynamics 2000; Rysin and Savelieva 2007). The map of vegetation of the Moscow region is developed (1:200 000 scale, ed. by Ogureeva 1996) which is based on the materials of forest inventory data and field research. Later, the list of community types used for the "Explanatory text and map legend" (Ogureeva 1996) was significantly revised and supplemented (Suslova 2019).

A number of papers dedicated to the environmental and socio-economic prospects of New Moscow development are known (Komarova 1997; Golubchikov 2012; Makhrova et al. 2013; Kuricheva 2014; Lurie et al. 2015; Ataev-Troshin 2017; Nefedova 2017). Economic assessments of ecosystem services in the strategies of socio-economic development in the implementation of individual megaprojects are known (Economy of biodiversity conservation 2002; Ecological and economic index... 2012). The existing losses of ecosystem services of natural landscapes are calculated for the territory of Moscow (New Moscow with an area of about 160 thousand hectares) which amount to about 10 trillion rubles (Tishkov 2014).

Despite the long history of studies in the region, the assessment of the current state of forests in the Moscow region is still not developed, and there are questions unanswered left in relation to the dynamics of forests and the possibility of forecasting their environmental and recreational potential. Available information is limited to the Forestry Committee of the Moscow region's annually updated data on the areas covered by the main types of forest stands of different age classes on designated forest lands and lands of defense and security. The lack of up-to-date information on the structure and composition of the Moscow region forest cover makes it impossible to assess the current state of forests and their respective socio-environmental functions. This information should also include regularly updated digital maps of typological forest diversity.
The purpose of this work is to inventory the current typological forest compositions and to develop tools for sustainable environmental management in the Moscow region. The first part of the study is performed with modern digital technologies, including modeling. The second part is based on the conceptual model "PRS" (OECD 1993).

Present study is the follow-up of the approach based on the system of indicators of forest state assessment of the Moscow region (Levitskaya and Chernenkova 2012). It is also follow-up of studies on the identification of the forests typological composition in the region performed by Chernenkova et al. (2015; 2018; 2019).

\section{MATERIAL AND METHODS}

In selecting the best tools for sustainable environmental management, the PSR model not only assesses the state of forests, but also determines the main impacts on them, as well as the effectiveness of measures aimed at optimizing environmental management regimes to maintain forest biodiversity. In accordance with the criteria of the model, we propose to perform a componentby-component assessment of the main indicators in relation to urban districts of the Moscow region - units of municipal management according to the reform of 2019. Table 1 contains the list of criteria and indicators for forest management, used to assess forest condition and processes - the pressure and response measures to maintain forest biodiversity. Finding the relationship between the Pressure, State and Response components of the model forms a mechanism to maintain a certain quality of forest cover.

When formulating a set of indicators, we proceeded from the following requirements: 1) consistency with the list of the main criteria and indicators generally accepted in national and international practice;

2) the possibility of obtaining official statistics;

3) the possibility of obtaining data and processing them using independent sources (field- and remote sensing data); 4) the possibility of obtaining quantitative 
Table 1. Criteria and indicators of forest management in the Moscow region

\begin{tabular}{|c|c|}
\hline Criteria & Indicators \\
\hline \multirow{5}{*}{$\begin{array}{c}\text { Pressure - effects } \\
\text { of natural and } \\
\text { anthropogenic factors } \\
\text { on forest cover }\end{array}$} & $\begin{array}{l}\text { The area of forest- and tree cover loss (ha) as a result of } \\
\text { construction, logging, fires, pest and forest diseases, adverse } \\
\text { weather conditions, etc. }\end{array}$ \\
\hline & Built-up area (ha) \\
\hline & $\begin{array}{l}\text { The overall impact on the forest (the ratio of human population } \\
\left.\text { to the area of urban district (persons } / \mathrm{km}^{2}\right) \text { ) }\end{array}$ \\
\hline & Agricultural land area (ha) \\
\hline & Environmental pollution (emissions (tonnes)) \\
\hline \multirow{3}{*}{ State of forest cover } & $\begin{array}{l}\text { Typological diversity (the proportion of nominally primary } \\
\text { forests (\%)) }\end{array}$ \\
\hline & Forest area (ha) \\
\hline & $\begin{array}{l}\text { Spatial structure of forest cover (fragmentation metrics of area } \\
\qquad(\mathrm{ha}) \text {, shape, proximity }(\mathrm{m}))\end{array}$ \\
\hline \multirow{2}{*}{$\begin{array}{l}\text { Response - measures } \\
\text { to maintain forest } \\
\text { biodiversity }\end{array}$} & Area (ha) and number of SPNA \\
\hline & Reforestation (ha) (natural and plantation) \\
\hline
\end{tabular}

estimates and calculating complex indicators of environmental value for the territory.

The resulting list of the main forest cover indicators corresponds well with the conceptual approach of assessing their transformation in three main areas changes in their quality, quantity and spatial configuration reflected in the SLOSS model (Fig. 1).

The values of the indicators were evaluated within the urban districts, with the estimated values of the parameters converted into a unit area or presented in absolute units. All variables are given equal weight because there are no generally accepted priorities in ranking the parameters.

\section{Condition of forest cover}

Inventory of typological diversity of the forest composition is an important step towards identifying the conditions of sustainable environmental management. To assess the current composition of forest cover, an approach integrating ground and remote sensing data was applied.

The analysis used the results of field descriptions (about 1500 geobotanical descriptions on the area of $400 \mathrm{~m}^{2}$ ). The localization of the points is related to the surface coverage of habitats, heterogenity in vegetation composition, soil composition and origin of rock material. Land cover types not presented in the descriptions (agriculture fields, water bodies, human settlements) were added to the training sample, based on visual analysis of the remote sensing data. Thus, about 2500 more points used in the training sample were obtained.

The analysis of spatial distribution patterns of selected syntaxons and their cartographic mapping, consisted in interpolation of vegetation classes to the upper-scale levels, by relating the training sample to remote sensing data and a digital elevation model (DEM) (Puzachenko et al. 2014; Chernenkova et al. 2018). The forest formation ${ }^{3}$ was the basic unit to be mapped, and was used as a grouping variable for multivariate analysis

${ }^{3}$ Formation - the unit of classification, which is defined by the edificator of the tree layer and it includes indication dominant species of trees. 
of multispectral images. Data from Landsat satellites (TM, ETM+, OLI and TIRS sensors) and SRTM v3 data, as DEM, were used. The methodology used is covered in more detail in earlier publications (Puzachenko at al. 2014; Chernenkova et al. 2015; Puzachenko and Chernenkova 2016).

On the basis of the developed forest cover map, the area and the proportion of nominally primary forests were estimated within the urban districts.

Informative indicators of the quality of forest cover are landscape-ecological metrics of fragmentation of forest stands (McGarigal et al. 2012). To determine effective indicators the metrics were calculated by urban district. A comparative study of their correlation tables was carried out. As a result, for further analysis, three most simple and informative indicators were selected - the metric of the patch (an area of homogenous forest type located on relatively homogenous soil type and homogenous form of relief) area, the diversity of the patch shape, and the patch isolation.

The average patch area is the basic indicator of fragmentation for any spatial units. To calculate the metric in the context of urban districts, the area-weighted average was used. Emphasizing the importance of larger patches, the weighted average calculation of the metrics focuses on the characteristics of the forest area as a whole, rather than forest patches (with simple averaging) (Jaeger 2000).

A number of studies have shown that shape metrics (shape index, perimeter/ area ratio, contiguity etc.) are indicators of many environmental processes, in particular, the intensity of seed propagation and overgrowth (Hardt and Forman 1989), affect the migration and foraging strategies of forest animals (Forman 1986; Buechner 1989). The main feature of the shape metrics is the indication of quantity and quality of ecotones, edges and boundary habitats. Shape index (SI) is the most simple and straightforward indicator of complexity of the contours (Fridland 1972; Patton 1975).
$S I=\frac{0.25 p_{i j}}{\sqrt{a_{i j}}}$

where $p_{i j}$ is the perimeter of the patch; $m, a_{i j}$ is the area of the patch, $m^{2}$. The metric value varies from 1 (for a square shape) to infinity. In contrast to the simple perimeter/area ratio, the shape index is not sensitive to the size of patches.

Aggregation metrics show the degree of fragmentation and mutual mixing of different classes of vegetation among themselves - formations in our case. In particular, isolation of forest patches is the simplest metric associated with the theory of island biogeography (MacArthur and Wilson 1967) and the theory of metapopulations (Levins 1970). It is shown that isolation of local subpopulations affects the state of metapopulation and is critical for habitats of protected species (Lamberson at al. 1992; McKelvey et al. 1992). Isolation is measured as the euclidean nearest neighbor (ENN) distance between the closest to each other patches of the same type.

$E N N=h_{i j}$, where $h_{i j}$ - distance $(\mathrm{m})$ from patch to nearest neighboring patch of the same type (class), based on patch edge-to-edge distance, computed from cell center to cell center.

\section{Pressure - effects of natural and anthropogenic factors on forest cover}

To identify the main types of pressure on natural habitats (Table 1) official statistics for 2007-2018 (Federal State Statistics Service 2019), data obtained from remote sensing surveys were used as sources of information. In particular, information from large-scale global remote sensing survey (based on Landsat satellite data (Hansen et al. 2013) was used to estimate the area of forest cover loss and gain in the period 2000-2012). The main part of the study was carried out in 2013, but the clarification and annual update occurs annually.

\section{Response - measures to maintain forest biodiversity}

The size of SPNA is a priority parameter in assessing the sustainability of forest 
management (The Ministerial... 1993; 으 Montreal... 1995), because only protected areas provide possibility of effective conservation of species and ecosystem diversity, creating conditions for the spontaneous flow of natural environmental processes. In SPNA nominally primary and secondary forests of different types were described on 450 sample plots. A comprehensive assessment of sets of indicators for each group of criteria PSR was performed for an integrated multicriteria assessment of sustainable forest management within the borders of the urban districts. Each indicator in the group was normalized to scores from 0 to 1 , and the average normalized score was calculated for each group of criteria. Correlation between scores of groups of criteria were estimated, classification of urban districts was performed on a ratio of groups of criteria by K-means method. The indicator values, resulting from componentby-component assessment, are presented in form of tables and map charts.

Multivariate statistical methods were employed in data processing using the software packages STATISTICA and IBM SPSS Statistics (correlation, regression and discriminant analyses). The standard ArcMap software products were the means of geoinformation analysis and visualization of the results.

\section{RESULTS}

In accordance with the adopted methodological approach, reflecting the causal relationship between impacts and changes in forest cover, the following results were obtained on the main indicators of State, Pressure and Response.

\section{State of forest cover}

Typological composition of forests. The forests on the sample plots were classified to 18 syntaxons at the level of formations. The results of interpolation of forest vegetation classes by discriminant analysis allowed to estimate the diversity of forest cover throughout the region and to develop a map of vegetation cover (Fig. 2). Here and elsewhere according to the tradition of Russian geobotany, forestry and dendrology under small-leaved we mean birch, aspen, alder, and under broad-leaved we mean oak, lime, maple, ash.

$51 \%$ of the Moscow region is forested, and $40 \%$ of the forest area is predominated
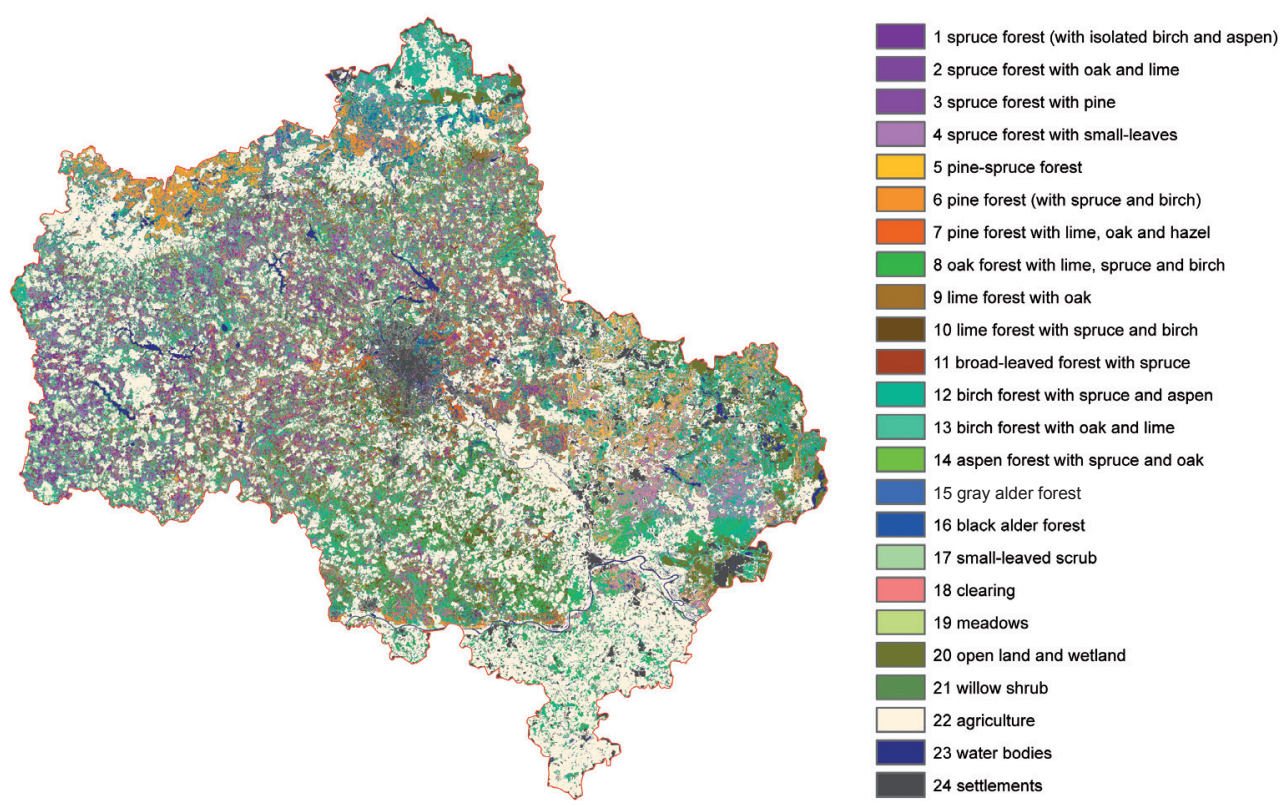

Fig. 2. Map of forest formations in the Moscow region 
by small-leaved species. The main forest forming small-leaved species are birch (Betula pendula, B. pubescens), aspen (Populus tremula), gray alder (Alnus incana), and willow (Salix spp.). The vast majority of small-leaved forests are secondary succression from coniferous, broad-leaved - coniferous and broad-leaved forests. Typological diversity of small-leaved forests is quite high, due to the variability of landscape conditions and a wide range of forests at different succession stages. Primary forest communities of alder (Alnus glutinosa, A. incana) and white willow (Salix alba) exist in riparian habitats, floodplains and in wetlands.

Spruce small-leaved communities are presented by a short-secondary succession of forests formed on-site from smallleaved forests. This type of community has very diverse understorey, including boreal species (Oxalis acetosela, Rubus saxatilis, Gymnocarpium dryopteris, Maianthemum bifolium, Orthilia secunda, Pleurozium schreberi, Hylocomium splendens, Rhytidiadelphus triquetrus) which combine in different proportions with nemoral species (Carex pilosa, Galeobdolon luteum, Asarum europaeum, Pulmonaria obscura, Athyrium filix-femina, Ranunculus cassubicus, Aegopodim podagraria, Cirriphyllum piliferum, Eurhynchium angustirete). The proportion of spruce - small-leaved forests within the total forest cover is $13 \%$.

The compositions of spruce forests vary (combinations of spruce with birch, aspen, pine and broad-leaved species), and largely characterize the compositions of primary forests in the coniferous - broad-leaved zone. The proportion of plantations is high (mainly spruce mono cultivation). The understorey vegetation ranges from boreal to nemoral species compositions. The structure of spruce forest of the boreal group (small-herb-green-moss and green-moss) shows up a relatively small number of types of communities, while subnemoral (smallherb - broad-leaved herb) and nemoral (broad-leaved herb) groups of spruce forests have larger coenotic diversity. This is both due to the greater presence of other tree species, and to the diversity in ground cover dominant species. The total area of spruce forests is $12 \%$. The area of distribution of boreal small-herb - green-moss spruce forests is small (about 1.5\%) with their predominance in the North-Western part of the region. Spruce forests with broad-leaved herb have the largest distribution and equals more than half of the total spruce forests area. This type also has a high proportion of plantation spruce trees.

Pine and pine-spruce forests on watershed surfaces are not fully primary communities and represent successional stages in in transition to more nature forests. The absence of pine regeneration in communities of automorphic (watershed ${ }^{4}$ located) habitats indicates the origin of pine forests after fires and cutting, as well as in plantations. In one case, restoration is accompanied by active regeneration of spruce forests; in another case on rich soil - broad - leaved species, which supersede pine and pine-spruce communities within a few decades. A small proportion of pine forests will remain on the steep slopes of river valleys due to pine-friendly environmental conditions (light sandy soils with good drainage) with constantly maintained recreational effects, as well as in hydromorphic (peatbog) conditions. On the dry and poor sandy soils of Meshchera physiographical province (on the East of the region) there are areas of natural lichen-green-moss pine forests with Calluna vulgaris, Convallaria majalis, Pulsatilla patents, Chimaphila umbellata, Jovibarba globifera, Veronica incana. In the sub-latitudinal direction, as in the case of spruce-small-leaved, spruce-broad-leaved and spruce forests, there is a different ratio of communities with a predominance of plant species of the boreal, subnemoral and nemoral layer in the understorey. The total forest area with pine communities in the Moscow region is about $15 \%$.

Forests with broad-leaved species retained the main features of pimary broadleaved coniferous forests - mixed species composition, multi-storey forest structure and rich species composition. Spruce broad-leaved forests with broad-leaved

\footnotetext{
${ }^{4}$ Watershed is an elevated terrain that separates neighbouring drainage basins
} 
herb communities are characterized by a a close proportion in the ratio of spruce and broad-leaved tree species (oak, lime and maple) in the upper understorey of the forest. The largest area of distribution of patches of broad-leaved - coniferous forests is located in the Central and Western parts of the study area, while the southern part is dominated by broad-leaved forests, which confirms the zonal transition on the Pakhra river (Petrov 1968) from broadleaved - coniferous forests to broadleaved ones. The latter are represented by oak, lime-oak and broad-leaved herb lime forests, often mixed with maple. Oak forests typically have a constant presence of Corylus avellana (coverage about 30\%) in the understorey, other shrubs are rare. In the herb layer there are common broad-leaved herb species - Galeobdolon luteum, Aegopodium podagraria, Asarum europaeum, Carex pilosa, Ajuga reptans, Geum rivale, Pulmonaria obscura. In lime forests hazel is less frequent compared to oak forests in terms of presence cover (average 8\%). Euonymus verrucosa is quite often occurs in lime forests. The herb cover is dominated by Carex pilosa, Aegopodium podagraria, Galeobdolon luteum, Pulmonaria obscura, rarely - Mercurialis perennis.

South of the Osetr river in the watersheds in several SPNA the primary broad forests are composed by oak, lime, maple, elm and ash, with shrubs (Corylus avellana, Lonicera xylosteum, Euonymus verrucosa) with broad-leaved herbs. In addition to the typical nemoral species here are also found Corydalis marschalliana, Dentaria quinquefolia and Allium ursinum. The undergrowth of Acer campestre is common in these forests. On the slopes of the river valleys the shrubby steppe oak forests with thorns and cherries occur.

In general, when a fairly arbitrary division of a nominally ${ }^{5}$ primary and secondary forests is made, the secondary ones slightly dominate. The distribution of these two forest categories by area is presented in table Eq. (A. 1).
The number of forest species listed in the Red book of the Moscow region.

The third edition of the Red Data Book of Moscow region includes 675 species of flora and fauna which need special protection measures. This includes 300 objects of flora: 206 species of vascular plants, 25 species of moss, 3 species of algae, 40 species of lichens and 26 species of fungi (Red Data Book 2018). There are more than 400 forest dependent species - among them representatives of fauna, plants, fungi and lichens. The distribution of protected forest species among urban districts varies widely. It should be taken into account that the number of such species is related not only to the degree of preservation of species diversity in natural communities, including the rare and protected species, but also it is directly dependent on biotopic and consequently cenotic diversity. An example of this is the representation of the maximum number of protected forest species in the Serpukhov urban district (200 taxa), associated with the presence of complex pine forests, coniferous - broad-leaved and broad-leaved forests, wetlands and foreststeppe communities on the terraces of the Oka river and species protected within Prioksko-Terrasny state biosphere reserve. Good knowledge of protected ecosystems is also an important factor Eq. (A. 1).

The structure of forest cover (landscape metrics). The size of weighted average patch area in urban districts varies from 89.8 ha (Khimki) to 52966 ha (Serebryanye Prudy). The size of the region's weighted average patch area is equal to 606.9 ha.

The range of shape index is from 2.06 (Khimki) to 16.57 (Zaraisk). The weighted average shape index in the region is 3.39 . Urban districts with the most fragmented forests (according to the shape index) are Naro-Fominsky, Solnechnogorsky, Shchelkovsky, Pushkinsky, Mytishchi, Istra, Ruzsky, Krasnogorsk and Odintsovsky. The most diverse shape index of forest patches are found in the urban districts Kashira and Serebryanye Prudy.

${ }^{5}$ nominally primary community - human influenced in the past, but restored to its most essential properties (floral composition, storey structure, environmental conditions). 
Isolation metric (the shortest distance between homogeneous forest stands) varies from 209 m (Zaraisky) to 257 m (Ruzsky). The smallest isolation is typical for urban districts of Kolomensky, Lukhovitsky and Serebryanye Prudy. The largest isolation is typical for the Istrinsky and Moscow. Weighted average isolation for the region is $233.5 \mathrm{~m}$.

\section{Pressure - effects of natural and anthropogenic factors on forest cover}

\section{Deforestation and natural disasters.} Forests in the Moscow region are periodically exposed to natural disasters: fires, pests, adverse weather conditions and diseases according to Review of the forest pathology and sanitary condition of forests in the Moscow region (2009; 2010). Wood harvesting practiced by commercial felling in mature and overmature stands by sanitary cutting of dead and damaged forest stands; by clearing forest for construction of roads, pipelines, and so on. More than half of the wood volume is currently harvested through non-commercial fellings (mostly sanitary clear cuttings). In this regard, the issue of attributing the factor of "cutting" to the group of indicators "impact" becomes controversial, since the main purpose of cuttings should be aimed at maintaining the stability of forest ecosystems. In reality, mainly coniferous forests that have reached the age of technical maturity are subject to cutting. And overmature small-leaved trees are due to implementation difficulties not harvested, and remain as dying and dead wood in the forests, worsening their sanitary condition (Yakubov 2007). However, since the area of cuttings indirectly reflects the amount of damaged forests, the table Eq. (A. 1) gives the area of forest losses for the period 2001-2012.

Development and recreation. The negative impact of urban development (both civil and industrial) is primarily due to the direct rejection of natural land for economic needs, resulting in the disturbed continuity of natural space, destroyed habitats cenopopulations $^{6}$ of animals and plants. According to the dynamics of built-up areas in the urban districts in 1992-2008 (The Nature 2009), the biggest increase (4-7\%) was through cottage development near the capital, in the urban districts of the Central sector of the Moscow region.

Over the past five years since the expansion of its borders, the population density of Moscow has not changed, while in the Moscow region, as in the annexed territories, it has increased. In New Moscow, the population density increased by more than 30\% (in Novomoskovsk - 37\%, in the Troitsky district - almost 25\%). The most significant growth was observed in the Moskovsky and Vnukovsky municipalities, which actively built up thanks to its proximity to the core of the region, the availability of territorial resources and the development of transport infrastructure. Less significantly, the population density increased in the settlements of Kievsky, Sosenskoye, Troitsk and Shcherbinka: the population of these territories increased by 30-50\% (Makhrova and Kirillov 2018).

A relatively new type of anthropogenic impact on the natural habitats in the region is the lease of forest areas for recreational purposes. Leasable areas can be delimited by very solid fences that impede wildlife migration. In addition, the list of permitted construction projects on forest lease plots is wide and allows to doubt in the longlivety of the forest in the territory. The most attractive lease areas are those near Moscow city, where the proportion of leased forests is more than $8 \%$ of the total forest area in the urban districts. The total proportion of builtup land is shown in the table Eq. (A. 1).

The ratio of the human population to the area of the urban district indirectly characterizes the recreational pressure on forest ecosystems and is conventionally called the total impact on forests Eq. (A. 1). In the last decade, the overall impact on forests, through the population density, has been increasing consistently and in 2018 averaged 347 people/ $/ \mathrm{km}^{2}$ (Federal State Statistics Service 2019).

\footnotetext{
${ }^{6}$ Cenopopulation - assemblage of individuals of a species within one phytocenosis occupying a certain habitat.
} 
Agricultural lands occupy almost 1449 a thousand hectares according to Rosstat in 2008 (1 585 thousand hectares according to our map of the formation composition), which is more than a third of the region. This figure includes abandoned agriculture fields in the early stages of overgrowth. The intensity of agricultural land use in the urban districts of the region can indirectly be estimated by the area of agricultural land. The proportion of agricultural land is biggest in the Southern and South-Eastern parts of the region, and smaller in the Eastern, Northern and South-Western parts of the region Eq. (A. 1).

Environmental pollution is characterized by the total amount of pollutants from all stationary sources in 2017 ('000 tonnes) (Federal State Statistics Service 2019). The distribution of the indicator is presented by urban districts in the table Eq. (A. 1).

\section{Response - measures to maintain forest biodiversity}

The area of SPNA. Intact forest ecosystems in the Moscow region are now preserved mainly in SPNA. Totally Federal SPNA occupy an area of 70.9 thousand hectares, which is $1.5 \%$ of the Moscow region, and regional SPNA - about 178.0 thousand hectares $3.9 \%$ of the Moscow region (Smirnova and Levitskaya 2018). SPNA of regional significance are located in all physiographic provinces in the territory of the Moscow region. SPNA are represented in almost all urban districts of the Moscow region, excluding Khimki and Kashira. Mainly undisturbed coniferous, deciduousconiferous, deciduous and small-leaved forests are protected within the territory of 246 regional SPNA. The table Eq. (A. 1) shows the distribution of the ratio of the protected area of the total area of the urban district.

Over the years since the approval of the Layout of Development and Location of Specially Protected Natural Areas in the Moscow region in 2009, there have been several important events that led to changes in this document. In particular, the boundaries of the city of Moscow were expanded in 2012, in connection with which
7 regional SPNA located in the annexed territories were deprived of their protective status. Several new SPNA with a total area of about 12.5 hectares are included in the new edition of the Laouyt (resolution of the Government of Moscow region from 27.06.2017 No. 535/22 with changes in 28.01.2019). 20 new SPNA of previously planned are created during 2009 to 2019.

As a result of the planned reforms, including the creation of several large natural parks, the area of SPNA of regional importance will increase significantly: in the future 2020, together with Federal SPNA, it will occupy about $15.5 \%$ of the territory of the Moscow region.

Reforestation is a system of forest management activities that contributes to maintain sustainable forest management, especially for areas with active anthropogenic transformation of the natural environment. According to official statements (Federal State Statistics Service 2019), the forest cover increased with 53000 ha from 2000 to 2009 (Levitskaya and Chernenkova 2012). An independent reforestation assessment based on remote sensing shows an increase of 50000 ha from 2000 to 2009. Data from our study are generally consistent with the official statistics, and difference can be explained by unsufficient regeneration measures and, consequently, not full survival rate. At the same time, natural afforestation of meadows and arable lands tripled in recent decades, while the area of cropland decreased to half (Federal State Statistics Service 2019). On the first of January 2009, there were 288 thousand hectares of croplands in the region.

The highest rates of reforestation are observed in the urban districts of Dmitrovsky, Klin, Mozhaisk and Shatura (3.9 - 5.5 thousand hectares for the period 2000-2012). The urban districts'reforestation areas for the period 2001-2012 are reflected in table A. 1.

\section{Integrated estimation}

The integrated assessment of the state of forests in the urban districts of the Moscow region was carried out according to the following indicators: forest area, proportion of 
forest area in the urban district, the proportion of forest area that is nominally primary, weighted average indices: patch area, shape index and isolation.

Within the boundaries of the urban districts in the region, five classes of forest condition are allocated according to their ecological value, where 5 corresponds to the maximum ecological value and 1 is the value for minimum ecological value. Urban districts with the most valuable forests are concentrated on the North and East of the Moscow region. Egoryevsk, Shatura and Taldomsky have a maximum score of 5. Klin, Sergiev Posadsky and Dmitrovsky districts have a score of 4 (Fig. 3). The most disturbed (highly fragmented, small in area and represented by long-term small-leaved plantations) are forests of forest-steppe subzone and crop production - Zaraysk, Kashira, Serebrianye Prudy and Lukhovitsky. The unsatisfactory state is typical for urban districts adjacent to the axes of the South-Eastern transport corridors - Ryazan and Kashira roads - probably due to active urban development in the last decade. To this group the West-North-West part of the region - Volokolamsky, Lotoshinsky and
Shakhovskaya districts - historically the zone of meat and dairy cattle breeding.

"New Moscow" (\# 40), as seen from the map (Fig. 3), has indicators of the integrated environmental value of forest cover which means quite good state of forest.

\section{Pressure}

The assessment of anthropogenic pressure on the forests was carried out by the following indicators: amount of pollutants released into the environment; recreational pressure; the proportion of built-up land; the proportion of farmland; loss of forest. 5 classes of intensity of pressure are allocated (Fig. 4), where 5 corresponds to the maximum forest pressure and 1 is the value for minimum pressure.

The most unfavorable situation is in urban districts of Lyubertsy, Khimki and Voskresensk. In Lyubertsy and Khimki the highest pressure factor is from the high population density for the region (about 2500 people $/ \mathrm{km}^{2}$ ). In Voskresensky district the reason for the high pressure is due to very high emissions of pollutants from chemical industry $(653$

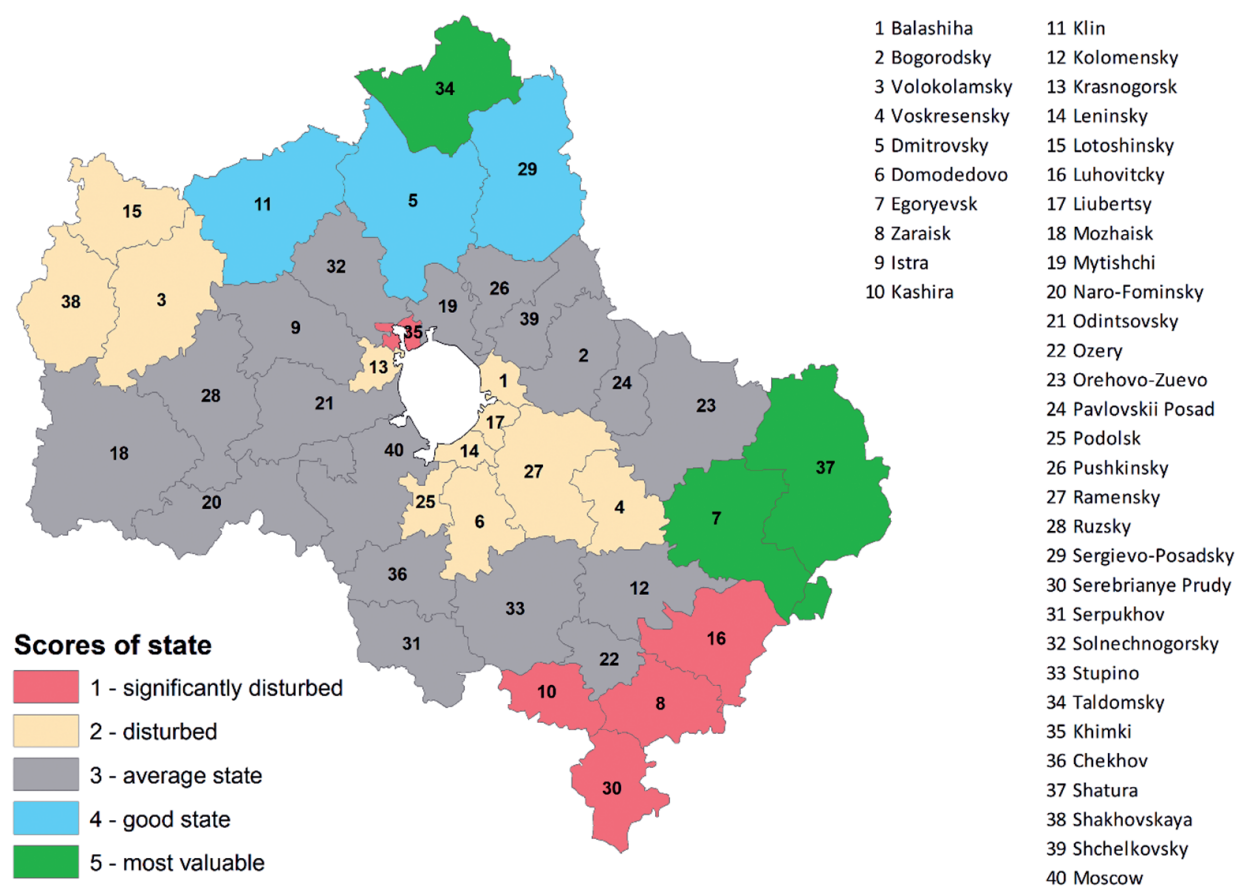

Fig. 3. Distribution of forest State indicators in the urban districts of the Moscow region 
thousand tons). In the East - South-East part highest response and 1 is the value for lowest response. Best response to pressure is found in Shatura district where almost close-tomaximum values are observed in all response indicators (more than 5 thousand hectares of the territory are reforested in 2001-2012, the highest area of SPNA (47 objects, which make up almost $20 \%$ of the urban district). Remote North-West urban districts have average or above average response scores: there are many active affoforestation processes and big area of SPNA.

Districts located near Moscow and within the strip to the South-East are characterized by the lowest level of response due to the small area of SPNA and little reforestation activities. One of the reasons for the little afforestation in this zone is the favorable cropping conditions, and thus less common to see abandoned agriculture fields. The area with high level of response is 5 times smaller than the area with low response.

\section{Criteria interconnection}

With the diversity and interaction of external factors affecting forest ecosystems in the region, it is important to assess the significance of their impact on the quality of forest cover.
The response criterion contains information on the increase in forest area and presence of SPNA in urban districts (total area of SPNA, their number and the proportion of the total area). 5 classes of response were allocated (Fig. 5), where 5 corresponds to the

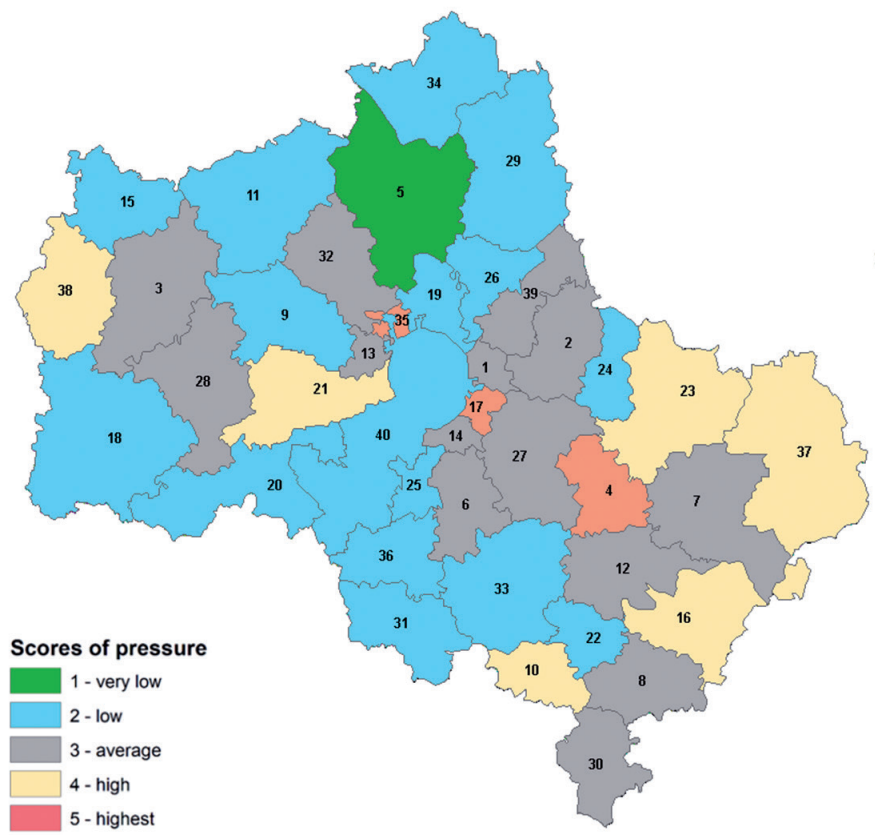

Fig. 4. Distribution of forest Pressure indicators in the urban districts of the Moscow region 


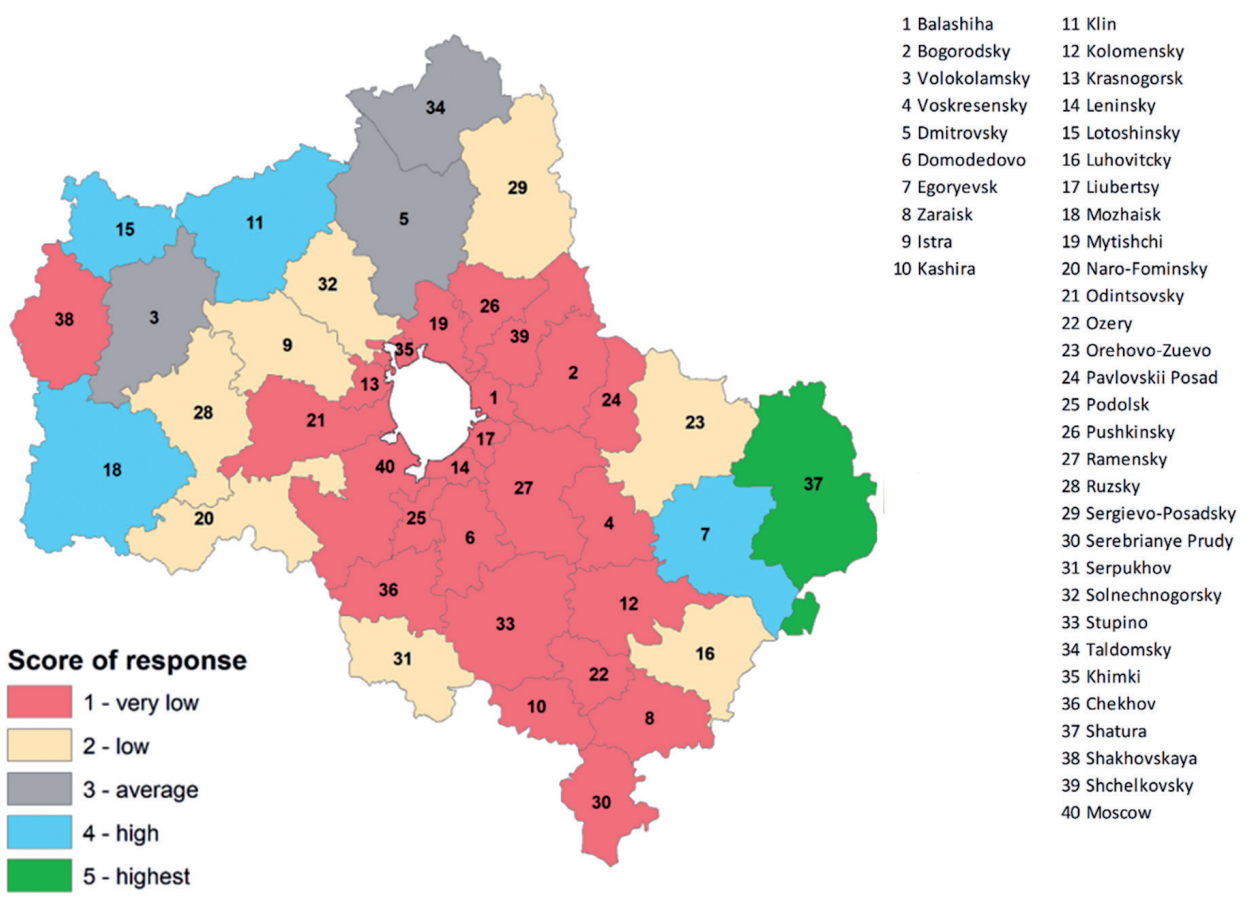

Fig. 5. Distribution of forest Response indicators in the urban districts of the Moscow region

To this purpose, the relationship between the main indicators of forest condition, pressure and response (Table 2) is considered. Pair correlations are calculated to assess the relationship between different criteria. Since not all distributions are normal according to the Kolmogorov-Smirnov criterion (the state and pressure criteria are rank type due to the nature of the measured parameters), Pearson and non pararametric Spearman correlations are used.

According to two correlation criteria, a significant relationship is observed between the state and response criteria (positive) and state and pressure (negative). The relationship between pressure and response is weak, unreliable, and has a negative sign.

Table 2. Pearson correlation coefficient and Spearman $r$ between indicators of state, pressure and response

\begin{tabular}{|c|c|c|c|c|c|c|c|}
\hline \multicolumn{2}{|c|}{} & \multicolumn{3}{c|}{ Pearson correlation } & \multicolumn{3}{c|}{ Spearman $r$} \\
\cline { 3 - 8 } \multicolumn{2}{c|}{} & Pressure & State & Response & Pressure & State & Response \\
\hline \multirow{3}{*}{ Pressure } & Correlation & 1.0 & $-0.339^{*}$ & -0.219 & 1.0 & $-0.394^{* *}$ & $-0.270^{*}$ \\
\cline { 2 - 8 } & Significance & & 0.016 & 0.087 & & 0.006 & 0.046 \\
\hline \multirow{3}{*}{ State } & Correlation & & 1.0 & $0.692^{* *}$ & & 1.0 & $0.687^{* *}$ \\
\cline { 2 - 8 } & Significance & & & 0.000 & & & 0.0 \\
\hline \multirow{3}{*}{ Response } & Correlation & & & 1.0 & & & 1.0 \\
\cline { 2 - 8 } & Significance & & & & & &. \\
\hline
\end{tabular}

* - significance level 0.05;

** - significance level 0.01 
Integrated evaluation of the three groups of criteria

To rank urban districts according to the nature of the pressure, state and response ratio, the classification of administrative units was performed by the K-means method. Five classes and relationship of three groups of criteria are presented in Table 3 and Figure 6.

The calculated scores of the three criteria and the assignment to one of the 5 classes are given in Table 4.

Table 3. Classes of urban districts by three criteria

\begin{tabular}{|c|c|c|c|c|c|}
\hline \multicolumn{2}{|c|}{ P-S-R class } & Pressure & State & Response & Description \\
\hline & 1 & 0.83 & 0.38 & 0.11 & $\begin{array}{c}\text { Low pressure. Average levels of } \\
\text { state and response. }\end{array}$ \\
\cline { 2 - 6 } Class \\
\cline { 2 - 6 } center & 3 & 0.51 & 0.18 & 0.06 & $\begin{array}{c}\text { Minimum pressure. Satisfactory } \\
\text { state and response }\end{array}$ \\
\cline { 2 - 6 } & 4 & 0.29 & 0.65 & 0.52 & $\begin{array}{c}\text { Average pressure. Highest level } \\
\text { of state and response }\end{array}$ \\
\cline { 2 - 6 } & 5 & 0.55 & 0.83 & 0.86 & $\begin{array}{c}\text { Minimum pressure. Average levels of } \\
\text { state and response. }\end{array}$ \\
state and response
\end{tabular}

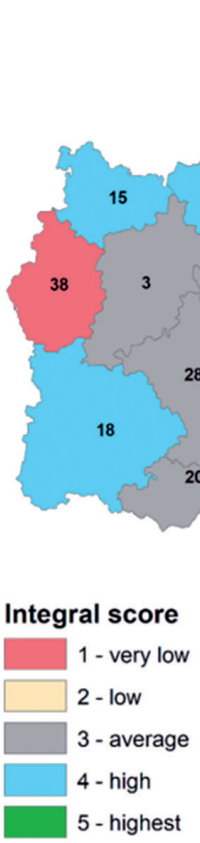

Fig. 6. Distribution of integrated forest scores in the urban districts of the Moscow region

$\begin{array}{cl}1 \text { Balashiha } & 11 \text { Klin } \\ 2 \text { Bogorodsky } & 12 \text { Kolomensky } \\ 3 \text { Volokolamsky } & 13 \text { Krasnogorsk } \\ 4 \text { Voskresensky } & 14 \text { Leninsky } \\ 5 \text { Dmitrovsky } & 15 \text { Lotoshinsky } \\ \text { 6 Domodedovo } & 16 \text { Luhovitcky } \\ 7 \text { Egoryevsk } & 17 \text { Liubertsy } \\ 8 \text { Zaraisk } & 18 \text { Mozhaisk } \\ 9 \text { Istra } & 19 \text { Mytishchi } \\ 110 \text { Kashira } & 20 \text { Naro-Fominsky } \\ & 21 \text { Odintsovsky } \\ & 22 \text { Ozery } \\ & 23 \text { Orehovo-Zuevo } \\ & 24 \text { Pavlovskii Posad } \\ & 25 \text { Podolsk } \\ & 26 \text { Pushkinsky } \\ & 27 \text { Ramensky } \\ & 28 \text { Ruzsky } \\ & 29 \text { Sergievo-Posadsky } \\ & 30 \text { Serebrianye Prudy } \\ & 31 \text { Serpukhov } \\ & 32 \text { Solnechnogorsky } \\ & 33 \text { Stupino } \\ & 34 \text { Taldomsky } \\ & 35 \text { Khimki } \\ & 36 \text { Chekhov } \\ & 37 \text { Shatura } \\ & 38 \text { Shakhovskaya } \\ & 39 \text { Shchelkovsky } \\ & 40 \text { Moscow } \\ & \\ & \end{array}$


Table 4. Urban districts ranking by three criteria

\begin{tabular}{|c|c|c|c|c|}
\hline \multirow{2}{*}{ Urban districts } & \multicolumn{3}{|c|}{ Criteria } & \multirow{2}{*}{ Class } \\
\hline & Pressure & State & Response & \\
\hline Balashiha & 0.47 & 0.38 & 0.14 & 3 \\
\hline Bogorodsky & 0.47 & 0.42 & 0.10 & 3 \\
\hline Volokolamsky & 0.47 & 0.38 & 0.38 & 3 \\
\hline Voskresensky & 0.94 & 0.26 & 0.11 & 1 \\
\hline Dmitrovsky & 0.16 & 0.63 & 0.49 & 4 \\
\hline Domodedovo & 0.43 & 0.28 & 0.02 & 2 \\
\hline Egoryevsk & 0.48 & 0.81 & 0.72 & 5 \\
\hline Zaraisk & 0.47 & 0.08 & 0.05 & 2 \\
\hline Istra & 0.29 & 0.46 & 0.27 & 3 \\
\hline Kashira & 0.71 & 0.02 & 0.02 & 2 \\
\hline Klin & 0.37 & 0.66 & 0.59 & 4 \\
\hline Kolomensky & 0.45 & 0.44 & 0.10 & 3 \\
\hline Krasnogorsk & 0.55 & 0.32 & 0.04 & 2 \\
\hline Leninsky & 0.49 & 0.26 & 0.01 & 2 \\
\hline Lotoshinsky & 0.29 & 0.39 & 0.60 & 4 \\
\hline Lukhovitsky & 0.63 & 0.11 & 0.22 & 2 \\
\hline Liubertsy & 0.85 & 0.35 & 0.00 & 1 \\
\hline Mozhaisk & 0.26 & 0.59 & 0.59 & 4 \\
\hline Mytishchi & 0.36 & 0.42 & 0.12 & 3 \\
\hline Naro-Fominsky & 0.40 & 0.51 & 0.19 & 3 \\
\hline Odintsovsky & 0.73 & 0.53 & 0.14 & 1 \\
\hline Ozery & 0.36 & 0.48 & 0.08 & 3 \\
\hline Orehovo-Zuevo & 0.70 & 0.58 & 0.25 & 1 \\
\hline Pavlovskii Posad & 0.35 & 0.41 & 0.12 & 3 \\
\hline Podolsk & 0.38 & 0.21 & 0.03 & 2 \\
\hline Pushkinsky & 0.32 & 0.45 & 0.07 & 3 \\
\hline Ramensky & 0.51 & 0.32 & 0.07 & 2 \\
\hline
\end{tabular}




\begin{tabular}{|c|c|c|c|c|}
\hline Ruzsky & 0.49 & 0.50 & 0.31 & 3 \\
\hline Sergievo-Posadsky & 0.39 & 0.61 & 0.38 & 4 \\
\hline Serebrianye Prudy & 0.41 & 0.00 & 0.11 & 2 \\
\hline Serpukhov & 0.26 & 0.46 & 0.32 & 3 \\
\hline Solnechnogorsky & 0.55 & 0.50 & 0.19 & 3 \\
\hline Stupino & 0.25 & 0.51 & 0.09 & 3 \\
\hline Taldomsky & 0.25 & 1.00 & 0.47 & 4 \\
\hline Khimki & 1.00 & 0.18 & 0.00 & 1 \\
\hline Chekhov & 0.25 & 0.42 & 0.05 & 3 \\
\hline Shatura & 0.61 & 0.85 & 1.00 & 1 \\
\hline Shakhovskaya & 0.74 & 0.39 & 0.17 & 3 \\
\hline Shchelkovsky & 0.41 & 0.46 & 0.09 & 3 \\
\hline Moscow & 0.40 & 0.51 & 0.16 & 3 \\
\hline
\end{tabular}

In fact, the most optimal ratio of criteria is observed only in two urban districts - Egoryevsk and Shatura. Due to the remoteness and low pressure of the forest in the North and partly in the West - Dmitrovsky, Klin, Sergiev Posad, Taldom, Mozhaisk, and Lotoshinsky - are characterized by good integrated indicators, but for them there is already a decrease in the criteria of condition and response.

Separately, districts with the worst indicator values deserve attention. Among them there are adjacent to the Moscow district, Khimki, Liubertsy and Odintsovo, but also those in considerable distance to Moscow Shakhovskaya and Orekhovo-Zuyevo.

In addition, unsatisfactory forest ranking is observed in other districts adjacent to Moscow - Krasnogorsk, Leninsky, Domodedovo, Podolsk and Ramensky. In the South similar forest ranking is obtained for Zaraysk, Kashira, Lukhovitsy and Serebrianye Prudy.

Drawing up the ratio of indicators in the form of a matrix of pressures and the state of forest ecosystems gives an idea of the forest distribution in the urban districts of the region, according to their state (environmental value), depending on the total pressure (Table 5). The districts with the most valuable forest ecosystems are located in the upper right corner of the matrix. It is in such forests that conditions are created for the preservation and functioning of intact forest ecosystems. The lower right corner of the matrix is occupied by Yegoryevsk and Shatura, whose forest ecosystems are characterized by high value and at the same time experience high anthropogenic pressures. In the lower left corner of the matrix there are districts, whose forests are subject to high anthropogenic pressures and severely damaged - Kashira, Lukhovitsky, Shakhovskaya, and Voskresensky.

Analyzing the matrix of correlation between the state of forest ecosystems and indicators of response (Table 6), it is possible to assess the effectiveness of the system of protection of natural areas and the need for other measures to maintain forest biodiversity in the urban districts of the Moscow region. In particular, in Sergiev Posad, located in the upper right corner of the matrix, where it is necessary to create new SPNA. 
Table 5. Matrix of pressure and state of forest ecosystems in the urban districts of the Moscow region

\begin{tabular}{|c|c|c|c|c|c|}
\hline \multirow[b]{2}{*}{ Pressure } & \multicolumn{5}{|c|}{ State } \\
\hline & $\begin{array}{c}\text { Significantly } \\
\text { disturbed }\end{array}$ & Disturbed & Average state & Good state & Most valuable \\
\hline Very low & & & & Dmitrovskii & \\
\hline Low & & $\begin{array}{l}\text { Lotoshinsky } \\
\text { Podolsk }\end{array}$ & $\begin{array}{c}\text { Istra } \\
\text { Mozhaisk } \\
\text { Mytishchi } \\
\text { Moscow } \\
\text { Naro-Fominskii } \\
\text { Ozery } \\
\text { Pavlovskii Posad } \\
\text { Pushkinskii } \\
\text { Serpuhov } \\
\text { Stupino } \\
\text { Chehov }\end{array}$ & $\begin{array}{c}\text { Klin } \\
\text { Sergievo- } \\
\text { Posadskii }\end{array}$ & Taldomskii \\
\hline Average & $\begin{array}{c}\text { Zaraisk } \\
\text { Serebrianye } \\
\text { Prudy }\end{array}$ & $\begin{array}{c}\text { Balashiha } \\
\text { Volokolamskii } \\
\text { Domodedovo } \\
\text { Krasnogorsk } \\
\text { Leninskii } \\
\text { Ramenskii }\end{array}$ & $\begin{array}{c}\text { Bogorodskii } \\
\text { Kolomenskii } \\
\text { Ruzskii } \\
\text { Solnechnogorskii } \\
\text { Shchelkovskii }\end{array}$ & & Egorevsk \\
\hline High & $\begin{array}{c}\text { Kashira } \\
\text { Lukhovitcky }\end{array}$ & Shahovskaia & $\begin{array}{c}\text { Odintcovskii } \\
\text { Orehovo-Zuevo }\end{array}$ & & Shatura \\
\hline Highest & & $\begin{array}{c}\text { Voskresenskii } \\
\text { Liubertcy }\end{array}$ & & & \\
\hline
\end{tabular}

Reforestation activities are required in urban districts located in the upper left corner of the matrix. This is a fairly extensive list - urban district Zaraysk, Serebrianye Prudy, Kashira, Khimki, Podolsk, Balashikha, Domodedovo, Krasnogorsk, Leninsky, Ramensky, Shakhovskaya, Voskresensky, Lyubertsy and Lukhovitsky.

The system of SPNA effectively protects forest ecosystems in the urban districts of Dmitrov, Taldomsky, Klin, Yegoryevsk, and Shatura. These urban districts can be considered as model references.

To improve and maintain a proper quality of forest cover, the total area of SPNA should be increased in different natural provinces of the region, including large Natural parks in the West, North and East of the region. This includes also effective management of SPNA. Consolidation of existing SPNA and their component clusters, the identification of valuable forest communities and the creation of new SPNA, the organization of a network of ecological corridors, the real protection in the territory of zakazniks and nature monuments are also needed. It is not recommended to create highdensity monocultures in SPNA during reforestation, and in existing middle-age plantations regular thinning is necessary for the introduction of other tree species, both small-leaved and broad-leaved. It is also recommended to identify areas where natural reforestation is preferable. 


\section{CONCLUSION}

The assessment of current typological diversity of forests in the Moscow region and the territory of "New Moscow" on the basis of a joint analysis of both field- and remote sensing data is performed. As a result of the classification of forest vegetation of the study area, 18 syntaxons were allocated at the level of the formation composition of forests. An integrated assessment of the state of forest in the Moscow region and the territory of "New Moscow" using main forest management criteria and indicators, as well as the calculation of the dependence of indicators on different types of pressures for urban districts of the region carried out. The analysis of the efficiency of the existing system of SPNA and the process of reforestation in relation to the preservation of forest biodiversity in urban districts of the region is also performed.

It is shown that only two urban districts of the Moscow region have a balanced combination of state, pressures and response - Shatursky and Yegoryevsky. Another six districts, with minimal pressures, lack measures - reforestation and protection - to maintain forest biodiversity (the "response" criterion). These include Dmitrov, Klin, Lotoshinskiy, Mozhaisk, Sergiev Posad, and Taldomsky. The lack of response measures is observed not only for urban districts adjacent to Moscow, but also towards the West, East and especially the South of the region - Voskresensky, Shakhovskaya, Orekhovo-Zuevsky, Zaraysk, Kashira, lukhovitsky and Serebrianye Prudy.

The nature of the relationship between three forest management criteria was assessed. Positive relationship revealed between the indicators of "state" and "response", which shows up the trend of the conservation and rehabilitation of forests in forest-rich urban districts, while the most deforested regions are experiencing a shortage of measures for the protection of forests. This is confirmed by the nature of the relationship between pressure and response - weak negative and unreliable. A third set of criteria - the "state" and "pressure" is negatively connected. In fact, all three of the relationship suggests that the most valuable and intact forest areas have a minimum pressure and are secured by a network of SPNA and active process of forest regeneration. On the other hand, urban districts, whose forests are most fragmented and depleted, receive minimal conservation and reforestation support, and at the same time the burden on them obviously increases due to the pace of urban development and expansion of agricultural land. This fact shows a long-term imbalance in the management of forests and natural areas of the Moscow region. Among the likely short-term consequences there are the transition of forests from a state of natural forest to a more park-like state, which leads to the loss of natural stability and the ability of being sustained. This lead to an increase in the cost of their maintenance, which has to be paid by urban district budgets.

It is shown that a joint integrated assessment of the ecological value of the territory and an integrated assessment of the impact factors can be effective tool for decision support systems at the regional level. A characteristic feature of such system, built on the matrix of scores combination- neutralization of shortterm market factors and focus on mediumand long-term planning of steps to manage the natural areas of a large region.

Assessment of factors of natural and anthropogenic impact, as well as their mutual combinations, there should be the main component of the regulatory measures on the environment with the justification of a maximum allowable value of the impact. However, due to far-fromcomplete elaboration of the relationship between definition of optimal ecological state of complex ecosystems and the allowable anthropogenic impact on them, it is hard to talk about finding the maximum allowable pressure loads (Yakovlev and Evdokimov 2011).

In the situation of multifactor impact on natural ecosystems the solution of this problem becomes much more complicated. In addition, there is no clear relationship between the degree of exposure to external factors and changes in biodiversity parameters. Moreover, examples of 
increasing parameters of diversity in conditions of anthropogenic impact through allogeneic community's shifts were often recorded (Trubina and Vorobeychik 2012; Hansen et al. 1991; Ruotsalainen and Kozlov 2006; Zvereva et al. 2008; Diamond 1975; Ovaskainen 2002). Thus, within the framework of this study it is not possible to give a quantitative assessment of the maximum allowable pressure on forest ecosystems in the Moscow region without the developed criteria of the maximum allowable impact and the optimal state. The assessment of individual impact factors and their integrated values is a necessary step along the way. Therefore, an integrated assessment of the main factors impacting the forest in the region and an aggregation of these using the method of scoring is recommended.

\section{ACKNOWLEDGEMENTS}

This work was conducted in the framework of Institute of Geography RAS (project no. 0148-2019-0007) in terms of studying the composition of forest communities. The Russian Science Foundation (project no. 18-17-00129) supports studies of spatial analysis of forest biodiversity.

\section{REFERENCES}

Ataev-Troshin V. (2017). New Moscow / V. Ataev-Troshin. Briansk: GUP «Briansk obl poligr obedinenie» (in Russian).

Buechner M. (1989). Are small-scale landscape features important factors for field studies of small mammal dispersal sinks? Landscape Ecology, 2, pp.191-199.

Byazrov L. G., Dylis N. V., Zhukova V. M., Nosova L. M., Solntseva O. N., Uspenskaia N. M., Utkin A. I. (1971). The main types of deciduous and spruce forests and their derivatives in Malinsky forestry Krasnopahor forestry Moscow region. In: N. Dylis ed. Biogeocenological studies in broad-leaved spruce forests. Moscow: Nauka, pp. 7-150 (in Russian).

Chernenkova T. V., Morozova O. V., Belyaeva N. G. and Puzachenko M. Yu. (2018). Actual organization of forest communities with broad-leaved trees in broad-leaved-coniferous zone (with Moscow region as an example). Vegetation of Russia. 33, pp. 107-130. DOI: 10.31111/vegrus/2018.33.107 (in Russian with English summary).

Chernenkova T. V., Morozova O. V., Puzachenko M. Yu., Popov S. Yu. and Belyaeva N.G. (2015). Composition and structure of spruce forests of the southwestern part of Moscow region. Contemporary problems of Ecology. 9(7), pp. 820-833. doi.org/10.1134/ S1995425516070039

Chernenkova T. V., Puzachenko M. Yu., Belyaeva N. G., Kotlov I.P. and Morozova O. V. (2019). Characteristics and prospects of preserving the pine forests of the Moscow region. Lesovedenie. 5 (in print) (in Russian with English summary).

Diamond J. M. (1975). The island dilemma: Lessons of modern biogeographic studies for the design of natural reserves. Biol. Conserv., 7, pp. 129-146.

Dynamics of coniferous forests of the Moscow region. (2000). Moscow: Nauka (in Russian).

Ecological and economic index of Russian regions. Methods and indicators for calculation (2012). Moscow: RIA-Novosti, RGO, WWF.

Economics of biodiversity conservation. Handbook (2002) / A. A. Tishkov ed. Moscow: GEF project «Biodiversity Conservation», Institute of environmental Economics (in Russian). 
Federal State Statistics Service / Municipal Indicators Database. Available at: http://www. gks.ru/dbscripts/munst/munst46/DBInet.cgi [Accessed 27.05.2019]

Forests of the Eastern part of the Moscow region. (1979). Moscow: Nauka (in Russian).

Forests of the Southern part of the Moscow region. (1985). Moscow: Nauka (in Russian).

Forests of the Western part of the Moscow region. (1982). Moscow: Nauka (in Russian).

Forman R. T. T. and Godron M. (1986). Landscape Ecology. New York: John Wiley \& Sons.

Golubchikov S. N. (2012). What will the New Moscow be // Energy: economy, technology, ecology, 2, pp. 58-63 (in Russian)

Hansen A. J., Spies T., Swanson F., Ohmann J. (1991). Conserving biodiversity in managed forests. BioScience, 41 (3), pp. 382-392.

Hansen M. C., Potapov P. V., Moore R., Hancher M., Turubanova S. A., Tyukavina A., Thau D., Stehman S. V., Goetz S. J., Loveland T. R., Kommareddy A., Egorov A., Chini L., Justice C. O. and Townshend J. R. G. (2013). High-Resolution Global Maps of 21st-Century Forest Cover Change. Science, 342 (6160), pp. 850-853. Available at: http://earthenginepartners. appspot.com/science-2013-global-forest [Accessed 27.05.2019]

Hardt R. A. and Forman R. T. T. (1989). Boundary form effects on woody colonization of reclaimed surface mines. Ecology, 70, pp. 1252-1260.

Jaeger J. A. G. (2000). Landscape division, splitting index, and effective mesh size: new measures of landscape fragmentation. Landscape Ecol., 15, pp. 115-130.

Komarova N. G. (1997). The atmosphere and its pollution on the example of large cities of Russia // Life of the Earth. Issue 30. Earth science and ecology, pp. 142-157 (in Russian).

Konovalov N. A. (1929). Types of forests of Moscow region forestry. Proccedings on forestry experimental work. Central Forest Experiment Station. Issue 5. Moscow; Leningrad: "Selkhozgiz" (in Russian).

Kuricheva E. K. (2014). Territorial transformation of New Moscow under the influence of housing construction // Regional studies, 43(1), pp. 50-61 (in Russian).

Kurnaev S. F. (1968).The main forest types of the middle part of the Russian Plain. Moscow: Nauka (in Russian).

Lamberson R. H., McKelvey R., Noon B. R. and C. Voss. (1992). A dynamic analysis of northern spotted owl viability in a fragmented forest landscape. Conservation Biology, 6(4), pp. 1-8.

Levins R. (1970). Extinctions. In: M. Gertenhaber, ed., Some Mathematical Questions in Biology, Vol 2. Lectures on Mathematics in the Life Sciences. Amer. Math. Soc., Providence, Rhode Island, pp. 77-107.

Levitskaya N. N. and Chernenkova T.V. (2012). The Application of a Series of Indices for Assessing the State of Forests in Moscow Region. Lesovedenie. 6, pp. 14-29 (in Russian with English summary).

Lurie, I. K., Baldina, E. A., Prasolova, A. I., Prohorova, E. A., Semin, V. N. and Chistov, S. V. (2015). A series of maps of ecological and geographical assessment of land resources in the territory of New Moscow //Vestnik Mosk. Un., Series. 5. Geogr., no 4, pp. 49-58 (in Russian). 
MacArthur R. H. and E. O. Wilson. (1967). The Theory of Island Biogeography. Princeton: University Press, Princeton.

Makhrova A. G., Tkachenko L. la. (2013). Plans and realities of New Moscow: continuation or change of development vector // Environmental planning and management, 1(14), pp. 37-50 (in Russian).

Makhrovoi A. G., Kirillova P.L. (2018). New Moscow: old and new features of social and economic development. Old and New Moscow: trends and problems of development. Collection of scientific articles: Izd. IP Matushkina I. I., pp. 89-119 (in Russian).

McGarigal K., Cushman S.A. and Ene E. (2012). FRAGSTATS v4: Spatial Pattern Analysis Program for Categorical and Continuous Maps. Computer software program produced by the authors at the University of Massachusetts, Amherst. Available at: http://www.umass. edu/landeco/research/fragstats/fragstats.html [Accessed 27.05.2019]

McKelvey K., Noon B. R. and Lamberson R. (1992). Conservation planning for species occupying fragmented landscapes: the case of the northern spotted owl. In: J. Kingsolver, P. Kareiva, and R. Hyey, eds. Biotic interactions and global change. Sinauer Associates, Sunderland, MA, pp. 338-357.

Ministerial conference on the protection of forest in Europe (MCPFE). Sound forestry Sustainable development (1993). Helsinki: Ministry of Agriculture and Forestry.

Ministerial Conference on the Protection of Forests in Europe. (2015). Available at: http:// www.foresteurope.org [Accessed 27.05.2019]

Nefedova T. G., Mkrtchian N. V. (2017). Migration of rural population and dynamics of agricultural employment in the regions of Russian //Vestnik Mosk Un. Series 5. Geography, no 5, pp. 58-67 (in Russian).

OECD environmental indicators - development, measurement and use. Reference paper. (2003). France, Paris: OECD.

Ovaskainen O. (2002). Long-term persistence of species and the SLOSS problem. J. Theor. Biol. 218, pp. 419-433.

Ovaskainen O. (2012). Strategies for Improving Biodiversity Conservation in the Netherlands: Enlarging Conservation Areas vs. Constructing Ecological Corridors. Helsinki. Avaliable at: https://www.rli.nl/sites/default/files/u61/otso_ovaskainen___strategies_for_improving_ biodiversity_conservation_in_the_netherlands.pdf [Accessed 27.05.2019]

Patton D. R. (1975). A diversity index for quantifying habitat "edge". Wildl. Soc. Bull. 3, pp. 171-173.

Puzachenko M. Yu., Chernenkova T. V. (2016). Definition of factors of spatial variation in vegetation using RSD, DEM and field data by example of the central part of Murmansk region. Current problems in remote sensing of the earth from space. 13 (5), pp. 167-191. DOl: 10.21046/2070-7401-2016-13-5-167-191 (in Russian with English summary).

Puzachenko Y. G., Sandlerskiy R. B., Krenke A. N., Puzachenko M. Y. (2014). Multispectral remote information in forest research. Lesovedenie. 5, pp. 13-29 (in Russian with English summary).

Red Data Book of Moscow region. (2018). Moscow region: "Verhove” (in Russian). 
Review of the forest pathology and sanitary condition of forests in the Moscow region in 2008 and the forecast of the pathological situation for 2009. (2009). Pushchino (in Russian).

Review of the forest pathology and sanitary condition of forests in the Moscow region in 2009 and the forecast of the pathological situation for 2010. (2010). Pushchino (in Russian).

Ruotsalainen A. L. and Kozlov M. V. (2006). Fungi and air pollution: is there a general pattern? In: D. Rhodes ed. New topics in environmental research. Hauppauge: NY: Nova Science Publ., pp. 57-103.

Rysin L. P. and Savelieva L. I. (2007). Inventories of forest and biogeocenoses types. Moscow: KMK (in Russian).

Smirnova S. Iu., Levitckaia N. N. Features of development of system of especially protected natural territories in the Moscow region // Old and New Moscow: trends and problems of development. Moscow: Izd. IP Matushkina I.I., pp. 317-333 (in Russian).

Suslova E. G. (2019). Forests of Moscow region. Ecosystems: Ecology and Dynamics. 3 (1), pp. 119-190 (in Russian with English summary).

The Montreal Process. Criteria and indicators for the conservation and Sustainable management of temperate and boreal forests. (1995). Hull, Quebec: Canadian forest service.

The nature of the Moscow region: the loss of the last two decades. (2009). Moscow: Izd-vo TsODP (in Russian).

Tishkov A. A. (2014). Strategic resources for the development of New Moscow // Strategic resources and conditions for sustainable development of the Russian Federation and its regions. Moscow, pp. 134-143 (in Russian).

Trubina M. R., Vorobeychik E. L. (2012). Heavy industrial pollution increases the $\beta$-diversity of plant communities. Doklady AS USSR. 442(1), pp. 139-141 (in Russian).

Yakovlev A. S. and Evdokimova M. V. (2011). Ecological rationing of soils and their quality management. Pochvovedenie. 5, pp. 582-596 (in Russian).

Yakubov I. (2007). Around ten billion. Russian forest newspaper, 42. Available at: http:// oldsite.zapoved.ru/press-service/publications/detail.php?|D=11108 [Accessed 27.05.2019]

Zvereva E., Toivonen E. and Kozlov M. V. (2008). Changes in species richness of vascular plants under the impact of air pollution: a global perspective. Global Ecol. Biogeogr, 17, pp. 305-319. 